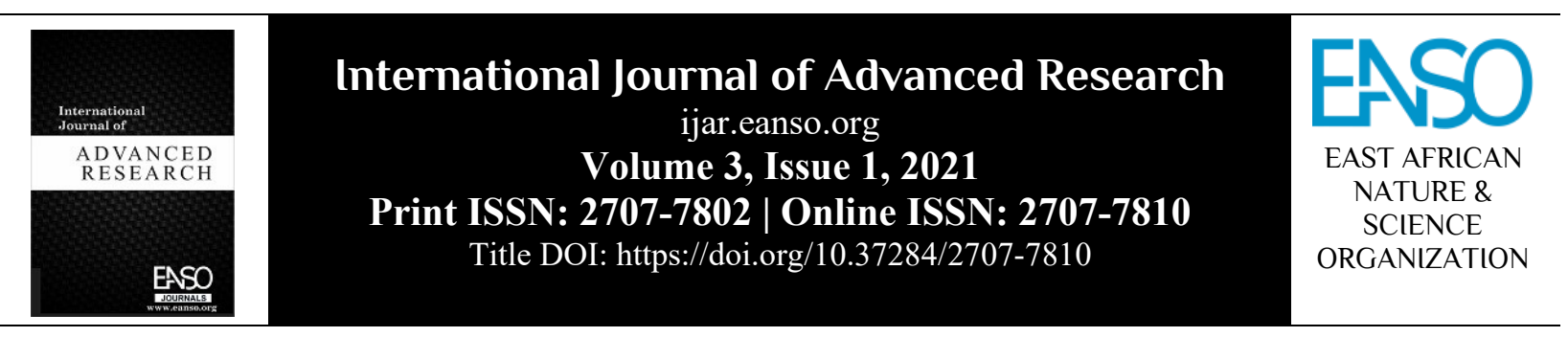

Original Article

\title{
Influence of Performance Appraisal in Determining Academic Staff Performance in Public Universities in Uganda
}

\author{
Joseph Rwothumio $^{I^{*}}$, Prof. Wilson Okaka, PhD ${ }^{I}$, Stephen Kambaza ${ }^{I}$ \& Eugene Kyomukama ${ }^{I}$ \\ ${ }^{1}$ Kyambogo University, P. O. Box 1, Kyambogo, Kampala, Uganda. \\ * Author for Correspondence email: rwothumiojoseph@yahoo.com.
}

Article DOI: https://doi.org/10.37284/ijar.3.1.281

Publication Date:

25 February 2021

Keywords:

Performance Appraisal, Academic Staff, Performance, Public University.

\section{ABSTRACT}

In an effort by public universities to improve the performance of lecturers in Uganda, universities are implementing annual performance appraisal. Despite this move, ineffective teaching, low research and publication continue to prevail, making it difficult for public universities to produce the needed human resources for national development. This study investigated the relationship between performance appraisal and teaching and research outputs of academic staff in selected public universities. A mixed method design using convergent parallel approach was employed to collect and analyse data from a population of 4 Vice-Chancellors, 4 Directors of Human Resources and 1127 full-time academic staff. Four universities were selected using purposive sampling based on the year of establishment before 2011 . The academic staff was selected by the use of the stratified random sampling technique. A total sample of 299 participants was involved made up of 291 academic staff, 4 directors of human resources and 4 Vice-chancellors in the study. Data collection employed the use of semi-structured questionnaires for the academic staff and interview guides for the Vice-Chancellors and Directors of Human Resources. Analysis of quantitative data collected was done using Pearson's Correlation, linear regression and factor analysis. Qualitative data was analysed based on thematic content analysis. Results indicated that a moderate positive relationship existed between performance appraisal and academic staff teaching output in public universities $(r=0.452$, $p<0.01)$ and a moderately positive relationship existed between performance appraisal and academic staff research output $(r=0.379, p<$ 0.01). It was recommended that Ugandan public universities need to revise the existing performance appraisal system to make it more relevant to the key work roles of academic staff of teaching and research outputs. 


\section{APA CITATION}

Rwothumio, J., Okaka, W., Kambaza, S., \& Kyomukama, W. (2021). Influence of Performance Appraisal in Determining Academic Staff Performance in Public Universities in Uganda. International Journal of Advanced Research, 3(1), 20-32. https://doi.org/10.37284/ijar.3.1.281

\section{CHICAGO CITATION}

Rwothumio, Joseph, Wilson Okaka, Stephen Kambaza, and Eugene Kyomukama. 2021. "Influence of Performance Appraisal in Determining Academic Staff Performance in Public Universities in Uganda". International Journal of Advanced Research 3 (1), 20-32. https://doi.org/10.37284/ijar.3.1.281.

\section{HARVARD CITATION}

Rwothumio, J., Okaka, W. Kambaza, S. and Kyomukama, W. (2021) "Influence of Performance Appraisal in Determining Academic Staff Performance in Public Universities in Uganda”, International Journal of Advanced Research, 3(1), pp. 20-32. doi: 10.37284/ijar.3.1.281.

\section{IEEE CITATION}

J. Rwothumio, W. Okaka, S. Kambaza, and W. Kyomukama, "Influence of Performance Appraisal in Determining Academic Staff Performance in Public Universities in Uganda”, IJAR, vol. 3, no. 1, pp. 20-32, Feb. 2021.

\section{MLA CITATION}

Rwothumio, Joseph, Wilson Okaka, Stephen Kambaza, and Eugene Kyomukama. "Influence of Performance Appraisal in Determining Academic Staff Performance in Public Universities in Uganda". International Journal of Advanced Research, Vol. 3, no. 1, Feb. 2021, pp. 20-32, doi:10.37284/ijar.3.1.281.

\section{INTRODUCTION}

This paper examined the influence of performance appraisal in determining academic staff performance in public universities in Uganda. Farndale, Vidovic and Rockey (2015) reported that most organizations are implementing performance appraisal practices in the United States of America in all levels of staffing as an aspect of human resource management. Kaya, Ergun and Kesen (2014) observe that among others, performance appraisal is one of the key human resource management practices with the potential to determine employee performance in Europe.

Performance appraisal in the view of Toppo and Prusty (2012) is when performance of employees is assessed in relation to their level of job performance. Performance appraisal is important in organisations because it is used as a basis for determining the level of staff performance. Roberts (2003) further notes that appraisal of performance is the process of promoting better organizational performance by reviewing individual academic staff task accomplishment. Also, performance appraisal gives feedback to employees on the positive and negative aspects of their performance which are likely to affect their performance. This human resource management practice is very critical in enhancing academic staff performance in public universities since it serves as a roadmap for assessing the individual as well as the general performance of institutions (Akpan, 2016). This study delimits performance appraisal practices to activities such as assessment of output, use of varied methods of assessment and provision of feedback on performance appraisal results.

In their discussion on academic staff performance, Kiriri and Gathuthi (2009) asserted that academic staff performance is teaching allocated workloads, attendance and presentation in conferences, book publications, articles in journals and academic staff career development. The Universities and Other Tertiary Institutions Act 2001 (as amended 2003 and 2006) singles out critical measures of academic staff output in terms of teaching; carrying out research and community service engagement. In addition, most public universities clearly spell out all key performance indicators for their academic staff. For instance, in staff manuals of Makerere University (2010), Mbarara University (2009), Kyambogo University (2015) and Gulu University (2016), members of academic staff are expected to lecture at least 10 hours and maximum of 12 hours per week.

This study was interested in how academic staff in public universities carries out their duties in relation to the teaching of allocated hours, timely assessment of students, time taken to complete marking of 
scripts and timely submission of results to the department. It also considered output of research as the total number of publications; papers presented in conferences both locally and internationally, and supervised and mentored a number of students to completion at all levels from undergraduate to graduate levels.

Taking a look at the level of productivity among doctoral holders in Uganda, Wamala and Ssembatya (2013) reported that there was low research productivity. This was being manifested in low levels of output in research as characterized by the limited number of books being authored and few publications by academic staff. The findings were however, contrary to the requirements of the National Council for Higher Education (2014) which demands that a university lecturer must produce new knowledge through research output in the form of published books and articles in recognized academic journals as indicators of quality and productive performance of academic staff. Turk and Roolaht (2017) carried out a study on appraisal of performance and reward in public and private Estonian universities in Northern Europe. The study revealed that university staff accepted to be appraised when it is aiming at individual and institutional improvement. This study therefore, focused on the relationship between performance appraisal and academic staff performance in selected public universities in Uganda.

\section{Statement of the Problem}

Public universities in Uganda are implementing performance appraisal to enhance academic staff performance as provided for in their human resource manuals. Public universities are also implementing the recommendations by the NCHE (2016) on performance appraisal as key human resource management practices among others to improve academic staff performance in universities. All organisations survive on well-established human resource management practices to ensure employee performance and higher educational institutions in Ugandan public universities are no exception.

Despite these moves, performance of academic staff in these institutions has not improved to the expected standards. Reports of poor lecturer performance in terms of ineffective teaching, low records of publications and inability to attract and win projects continue to prevail in most public universities in Uganda (McGregor, 2007; NCHE, 2016). Neglecting this situation may give rise to a failing future for public universities in Uganda. The country risks having university graduates who may fail to compete effectively in the global job market. This scenario has created the desire for a study to be developed to establish whether there is any relationship between performance and academic staff performance in Ugandan public universities. The study was guided by the following two objectives to determine the relationship between performance appraisal and academic staff teaching output in selected public universities in Uganda; to determine the relationship between performance appraisal and academic staff research output in selected public universities in Uganda.

\section{Research Hypotheses}

The null hypotheses formulated for the study included:

\section{$H_{01}$ : Performance appraisal has no statistically significant relationship with academic staff teaching output in selected public universities in Uganda.}

H02: Performance appraisal has no statistically significant relationship with academic staff research output in selected public universities in Uganda.

\section{THEORETICAL FRAMEWORK}

The research used the social exchange theory espoused by Homans (1958) and reviewed by Blau (1964). This theory explains what influences social behaviour in terms of interchange between material goods and non-material ones. According to Blau (1964) social exchange theory is a fundamental unit of social life, in which social structures are entrenched. Reciprocal obligations are initiated in social relations and interactions as people engage in bonds that are mutually acceptable and rewarding. Marescaux, De Winne and Sels, (2013) further elaborated that through the management in organisations, appraisal of performance initiates a positive and acceptable exchange relation. Thus, 
meeting the objectives for what they were hired for. Social exchange theory proposes that obligations are created through a chain of connections between the employers and employees who depend on each other through a relationship based on reciprocal interdependence. The theory, therefore, was the basis for relating performance appraisal and academic staff performance-teaching and research outputs in this study.

\section{LITERATURE REVIEW}

Staff performance appraisal is the assessment of employees in relation to their job performance (Toppo \& Prusty, 2012). Armstrong (2014), states that the assessment of performance provides an opportunity for managers and leaders of organisations to take stock of workloads and volumes of the performance of employees they have hired. This session of the review looked at empirical studies on practices in performance appraisal in connection to employee performance and academic staff performance in particular. In a related study Akpan (2016), looked at the appraisal of performance as a quality assurance instrument for teaching staff effectiveness in Nigerian public universities. The study focused on how performance appraisal would be embraced as a critical instrument for enhancing the quality of delivery of service among teaching staff in Nigerian universities. The study concluded that public universities in Nigeria should carry out assessment of teaching staff performance to identify potential candidates for promotion. The study recommended that public universities should redesign the academic staff appraisal system to deal with other issues such as academic staff past performance, quality of lecturing, students' assessment, future capabilities and weaknesses other than promotion.

Recently Menon (2017) critiqued teacher performance management in Indian higher education institutions. It was found that the observation cube should focus on the teacher as a facilitator, evaluator, researcher, mentor, guide, friend, counsellor, motivator, adept academic administrator and charismatic role model. This way the appraisal can be done in a multifaceted manner to capture all the potentialities of academic staff. The study concluded that in developing new performance appraisals, critical elements such as quality of research and the primary task of teaching should never be compromised but rather be enhanced during observations. Menon (2017) further added that teachers are an integral part of higher education institutions and their job profiles must entail teaching, research and academic administration.

In another study, Ojukuku (2013) explored the impact of appraisal of performance on the motivation and performance of academic staff in Nigerian Universities. A sample of four universities participated. The results indicated that lecturers perceived performance appraisal as not being fair and accurate since some of their job aspects were not captured in the review period. Performance appraisal further put considerable pressure on the level of academic staff motivation and performance. The study recommended that the performance appraisal system for academics need to be reconsidered to include all their job aspects.

Balakhanova, Danko, Midova and Minasyan (2017) carried research in Russia targeting the execution of recently introduced performance pay-based schemes in higher education institutions. The research established the extent to which performance pay-based schemes were likely to affect staff of higher educational institutions. The findings from the detailed analysis revealed that the performance of the university faculty rose to over $40 \%$ in the $2016 / 2017$ academic year in the total number of publications as compared to the 2014/2015 academic year when the performance pay-based scheme was not well developed. The study recommended that the university needed to empower lecturers to meet innovations and difficulties positively in order to be productive.

Turk (2016) had earlier carried out research on academic staff performance management and its effectiveness in universities in Estonia. The research aimed at identifying avenues for designing the management of performance among teaching staff. Results revealed performance management systems used in Estonian universities depend on profession-based systems which are contractual and has a term of 3-5 years. It also measures the hours of contact and volume of mentored theses or dissertations and the number of publications in different outlets. Hashim, Rafi, Kazmi, Ullah and 
Kee (2017) conducted research with a focus on three human resource management practices namely reward, promotion and performance evaluation on the output of Pakistan private universities. Findings indicated a positive linkage with compensation, promotion as well as outputs of lecturer output. The study concluded that academic staff is more concerned with performance evaluation practices in stimulating academic staff performance in private universities.

Palupi, Cahjono and Dananti (2017) presented a research paper aimed to construct indicators of appraisal of the performance of lecturers in Indonesia. This would use an evaluation model which is web-based integrated. The main intention of the certification reward granted by the government is meant to improve on the lecturers' performance. The performance appraisal indicators were formulated using the $360^{\circ}$ assessment to enhance the questionnaire. Focused Group Discussion was used to complete the performance appraisal indicators. The questionnaire had four competency parts namely: pedagogic, social, professional and personal competency. The results of this study contributed to performance management research by highlighting potential issues and challenges in performance appraisal implementation in universities found in developing countries such as Indonesia. At the end of the study, the researcher came up with strategies to enhance better influence of performance appraisal on academic staff performance.

Kyaligonza, Kimoga and Nabayego (2015) presented an article on the issue of funding research for lecturers in Ugandan public universities. The article focused on the bottlenecks and opportunities. The paper aimed at probing the funding sources for lecturers' research, assess the limit of existing financial support and determine other possible ways of obtaining financial support. Makerere University and Mbarara University were selected from the eight universities to participate based on their research experience, output and productivity. Research participants were interviewed and data generated from them were analysed by content analysis. The findings revealed that research funds come from government subvention, incomegenerating units and fees paid by students, together with donor funds which normally are directed to science-based disciplines. It was also revealed that the funding for research was inadequate which resulted in most lecturers in public universities doing research for academic interest in order to be promoted or awarded higher degrees. Generally, it was concluded that research activities are given little attention by universities in financial priorities. It was recommended that universities need to raise realistic fees without any government interference, seek more funding from donors and encouraging alumni contribute to their alma-maters.

\section{RESEARCH DESIGN}

The study employed mixed method research design by specifically employing the convergent parallel approach. Curtis (2008) defines mixed method in terms of research methodology that systematically integrates both quantitative and qualitative approaches contained in one study. In this study, the researcher merged the quantitative and qualitative data to avail an extensive analysis of the problem being researched. The independent variable was academic performance appraisal while the dependent variable was academic staff performance. The academic staff performance focused on teaching output as measured by teaching ten hours weekly; preparing course outlines; timely assessment of students; timely marking and return of scripts; timely submission of marks to the department. The other aspect of academic staff performance was research output as measured by research publications, papers presented, conferences attended and students supervised to completion.

\section{Location of the Study}

This research was done in the four Ugandan public universities. They were Kyambogo University located in Central Uganda; Mbarara University of Science and Technology located in Western Uganda; Gulu University in Northern and Busitema University in the Eastern region of the country. These public universities were selected based on the assumption that they have implemented human resource management practices since 2011 and have good experiences and records. They also represented each region of the country. This helped in giving a more representative view from the public universities in Uganda. 


\section{Target Population}

The target population (Table 1) comprised all the academic staff, directors of human resources and Vice-Chancellors making a total of 1135 . This included all the 1127 full-time academic staff who are on government payroll, all the four ViceChancellors and all the four directors of human resources in the selected public universities. Academic staff were included because they were the main focus of the study and human resource management practices directly targeted them. The directors of human resources and Vice-Chancellors were included because they formulate and implement human resource management practices in public universities. They had reliable information on the status of human resource management practices in public universities in Uganda. The Vice-Chancellors also perform a key duty to ensure that academic staff are provided with the required conditions to enhance their performance.

In addition, in accordance with the Universities and Other Tertiary Institutions Act 2001, ViceChancellor is the university's chief administrator, academic and financial officer. Therefore, their responses and suggestions were instrumental in this study. The academic staff served as the main respondents. The directors of human resources and Vice-chancellors served as key informants.

Table 1: Target Population and Selected Universities

\begin{tabular}{lllll}
\hline Public University & Lecturers & Director HR & Vice-Chancellors & Total \\
\hline Mbarara & 256 & 1 & 1 & 258 \\
Gulu & 279 & 1 & 1 & 281 \\
Kyambogo & 415 & 1 & 1 & 417 \\
Busitema & 177 & 1 & 1 & 179 \\
Grand Total & $\mathbf{1 1 2 7}$ & $\mathbf{4}$ & $\mathbf{4}$ & $\mathbf{1 1 3 5}$ \\
\hline
\end{tabular}

Source: (Uganda Ministry of Public Service, 2018)

\section{Sampling Techniques}

According to Lavrakas (2008) sampling frame is a comprehensive and credible list of the members of the population. To attain the right and good sample size, the researcher used a two-phase procedure for obtaining the sample; the first phase involved, public universities which started before 2011 were identified since they were more likely to have well documented human resource management practices and then clustered according to the regions. Then, universities that fall within this selection criterion were purposively selected. In the Central region, there are two public universities namely Makerere and Kyambogo Universities; but Kyambogo was selected because Makerere had been identified to be used in the pre-test phase. Since there is one public university in each of the remaining regions that was established before 2011, each was included in the study. Mbarara University was selected from
Western Uganda, Gulu University from Northern and Busitema University from the Eastern region. The academic staff were then finally chosen by use of simple random sampling. This ensured that the academic staff were given equal chances of participation in the study. The directors of human resources and Vice-Chancellors were purposively selected.

\section{Sample Size}

To get the appropriate size of the sample for academic staff, Vice-Chancellor and director human resource, the table designed by Krejcie and Morgan (1970) was used to determine the sample size from the given population. The academic staff sampled were 291 out of 1127 . The total sample size was 299 respondents made up of 291 lecturers, four directors of human resources and four Vice Chancellors. This is summarised in Table 2. 
Table 2: Sample size

\begin{tabular}{llll}
\hline Public University & Regional Location & Category of respondents & Sample \\
\hline Mbarara & Western & Academic staff & 66 \\
& & Vice Chancellor & 01 \\
& \multirow{3}{*}{ Nulu } & Director HR & 01 \\
& & Academic staff & 72 \\
& & Vice-Chancellor & 01 \\
Kyambogo & Central & Director HR & 01 \\
& & Academic staff & 107 \\
& & Vice-Chancellor & 01 \\
Busitema & Eastern & Director HR & 01 \\
& & Academic staff & 46 \\
& & Vice-Chancellor & 01 \\
Total & & Director HR & 01 \\
& & & $\mathbf{2 9 9}$ \\
\hline
\end{tabular}

\section{Research Instruments}

This involved the use of a semi-structured selfadministered questionnaire (SAQ). Qualitative data collection instruments involve collecting a large amount of data on a rather small, purposive sample. This study applied in-depth interviews (Gaiser \& Schreiner, 2009).

The study used a semi-structured questionnaire for academic staff because the targeted respondents were literate. The questionnaire was used to ensure greater assurance of anonymity, encourage on the spot collection of data, produce quick results and a wide geographical area could be covered within a short time. Structured questions were used because they facilitated the researcher to gather specific data on the six aspects of the study. Questionnaires also gave time to respondents to reflect on answers to avoid hasty responses to increase the level of correctness in the collection of data.

An interview guide was prepared for the ViceChancellors to collect data on the performance appraisal and how they relate to the performance of academic staff in the selected public universities. An interview guide was appropriate because it is able to collect in-depth data on the variables of the study. The key variables that were captured in the interview guide included: the relationship between performance appraisal practices and performance of academic staff in relation to teaching and research outputs in public universities in Uganda.
An interview guide was prepared for the directors of human resources, to ensure rich and in-depth data collected on the research variables. Data were collected on performance appraisal practices and how they related to the performance of academic staff in regard to their teaching and research outputs in public universities. This was considered important because the directors of human resources play a key role in effecting performance appraisal to enhance the performance of the teaching staff. An interview guide was employed in the collection of in-depth information from informants who were vital in the research. Interviews were used because the study targeted the respondents' real opinions on the research problem (Kvale \& Brinkmann, 2009). Questions for the interview targeted the major themes of the study.

\section{Validity of Questionnaires}

Validity is the capacity of the items in an instrument to measure what it is meant for depending on the study variables using experts' knowledge (Amin, 2005; Onen, 2014). The validity of the instruments was determined by two professors who are experts in human resource management in universities. One of the Professors came from Makerere University the Uganda's oldest university and the other from Makerere University Business School in Uganda. The views of these two professors were adequate in validating the items in the instruments prepared for the collection of data collection. The items were evaluated on a scale of $1=$ relevant and $2=$ not relevant. Relevant items were considered by the 
experts as having the ability to measure the variables under study. A Content Validity Index (CVI) was further employed to determine the validity of the instruments. The formula used in determining the content validity index was $\mathrm{CVI}=\mathrm{n} / \mathrm{N}$; where $\mathrm{n}$ is the number of items which was confirmed relevant; $\mathrm{N}$ is the total number of items in the instrument. A CVI of 0.7 and above was considered acceptable as noted by (Amin, 2005).

Table 3: Showing Content Validity Index (CVI)

\begin{tabular}{ll}
\hline Expert & Content Validity Index \\
\hline Expert 1 & 0.84 \\
Expert 2 & 0.89 \\
Average & 0.87 \\
\hline
\end{tabular}

As presented in Table 3 all the CVIs were above 0.7, meaning the items were relevant to the study variables. On average, the Content Validity Index was 0.87 which was in agreement with Amin (2005) who recommended that for any tool to be considered valid the CVI has to be 0.7 and above (Amin, 2005).

\section{Reliability of Questionnaires}

Reliability is the dependability of an instrument under similar circumstances to generate similar outcomes as observed by Amin (2005) and Onen (2014). The semi-structured questionnaire was administered to 30 academic staff at Makerere University. Makerere University was not among the selected universities for the study since its academic staff performance was relatively higher as compared to the other public universities. This was because of its historical background, the big size of the academic staff and quite rich experience in the East African region. The reliability of the tool for data collection was calculated using Cronbach's Alpha test of reliability. Cronbach's alpha is calculated by correlating the score for each scale item with the total score for each occurrence (using each respondents survey or participants in the survey), and then comparing that to the variance for all individual item scores as illustrated in the formula below:

$$
\propto=\frac{K}{K-1}\left(1-\frac{\sum_{i=1}^{k} \sigma_{Y_{i}}^{2}}{\sigma_{X}^{2}}\right)
$$

where: $\mathrm{K} / \mathrm{K}-1$ is the number of scale items; ${ }^{\sigma 2} Y_{i}$ is the variance associated with item i; ${ }^{\sigma 2} x$ is the variance associated with the observed total scores

This test determined the internal consistency of the items used to measure variables in the questionnaire. The data was entered into the computer and analysis was done using the SPSS Version 22. All variables had Alpha Correlation Coefficient of 0.7 and above hence taken to be reliable. Ahuja, Coff and Lee (2005) argue that a correlation coefficient of 0.7 and above is acceptable for research instruments

\section{Validity and Reliability of Interview Guides}

Interview guides collected qualitative data. Qualitative technique was used to ensure that both validity and reliability are determined. During the collection of data, the researcher investigated and interrogated the data collected by the use of methodological coherence; the researcher ensured research questions asked using the instrument matched with the method of data collection and analysis procedures (Creswell, 2014). The researcher continued to modify the questions and methods in the process of research in order to meet the research goals. Appropriateness of the nonrandom sample, in order to ensure the validity and reliability of the interview guides, sufficient data was obtained by the researcher to account for all aspects of the phenomenon being investigated. Collecting and analysing data concurrently, data from the interview guide was collected and analysed concurrently with the data from the questionnaire. Whittemore, Chase, and Mandle (2001) suggest that this is achieved by doing pacing and having an interactive approach between data and analysis will enable the researcher to attain validity and reliability.

\section{Data Analysis}

The analysis of quantitative data at univariate level was done using descriptive statistics including mean. Pearson correlation determined the significance of relationships between the predictor and outcome variables. The relationship between the variables as stated in the null hypothesis was determined based on the following coefficient 
values: $r=1.0$ perfect relationship, 0.7 to 0.99 high relationship, and $r=0.4-0.69 ;$ moderate relationship, $r=0.2-0.39$; weak relationship, $r=$ 0.01-0.19; very weak relationship and $\mathrm{r}=0$, no correlation (Creswell, 2014). Qualitative responses recorded in the notebook were analysed based on relevant themes. The themes were derived in line with the research objective as recommended by Trochim (2006). This narration helped to support the quantitative data.

\section{RESULTS AND DISCUSSION}

The first objective that guided the research was to determine the relationship between performance appraisal and research output of academic staff in selected Ugandan public universities. It had been hypothesized that performance appraisal had no statistically significant correlation with academic staff teaching output in selected public universities.
The findings showed in table 4.6 there was a moderate positive correlation $(r(2)=0.452, p<$ 0.01 ) between performance appraisal and academic staff teaching output in public universities in Uganda. The stated null hypothesis was rejected and restated as there was statistically a moderate positive relationship between performance appraisal and academic staff teaching output. Therefore, this result indicates a moderate positive relationship existed between performance appraisal and academic staff teaching output.

Exploratory factor analysis was used to explore the components of performance appraisal that strongly contributed to the relationship with teaching output. Components with eigenvalues greater than 1 were considered. An oblique solution was chosen, using a Varimax rotation, to have components that are correlated with one another.

\section{Table 4: Rotated Factor Matrix for Performance Appraisal}

\begin{tabular}{|c|c|c|c|}
\hline Aspects & $\begin{array}{l}\text { Component } \\
\text { Performance } \\
\text { improvement }\end{array}$ & $\begin{array}{l}\text { Training needs } \\
\text { identification }\end{array}$ & $\begin{array}{l}\text { Clear } \\
\text { Appraisal }\end{array}$ \\
\hline $\begin{array}{l}\text { This university has clear appraisal procedure for } \\
\text { academic staff performance }\end{array}$ & & & .302 \\
\hline $\begin{array}{l}\text { This university performance appraisal gives opportunity } \\
\text { to identify performance targets for academic staff }\end{array}$ & & & .825 \\
\hline $\begin{array}{l}\text { In this university performance appraisal is used to } \\
\text { identify academic staff training needs }\end{array}$ & & .793 & \\
\hline $\begin{array}{l}\text { In this University appraisal action plans discussed and } \\
\text { agreed between appraise and appraiser }\end{array}$ & & .618 & \\
\hline $\begin{array}{l}\text { In my university performance appraisal provides } \\
\text { opportunity to AS to improve research skills }\end{array}$ & .767 & & \\
\hline $\begin{array}{l}\text { Performance Appraisal provides opportunity for } \\
\text { academic staff to improve pedagogical skills }\end{array}$ & .827 & & \\
\hline $\begin{array}{l}\text { Performance Appraisal provides support to academic } \\
\text { staff to improve content delivery subject matter }\end{array}$ & .818 & & \\
\hline $\begin{array}{l}\text { Timely feedback on Job Performance is provided at } \\
\text { appraisal meetings }\end{array}$ & .755 & & \\
\hline $\begin{array}{l}\text { Performance Appraisal system of this university has } \\
\text { improved my job performance }\end{array}$ & .741 & & \\
\hline Eigen values & 4.494 & 2.950 & 1.223 \\
\hline Percentage total variance & 32.098 & 21.069 & 8.736 \\
\hline Cumulative percentage & 32.098 & 51.167 & 61.903 \\
\hline
\end{tabular}

An inspection of the factors indicated that component 1 was performance improvement focused and accounted for $32.1 \%$ of the variation, component two was training needs identification and accounted for $21 \%$ of the variation. Component 3 was a clear appraisal system and accounted for 8.8 $\%$ variation (Table 4). All three components accounted for $61.9 \%$ of the variation in 
performance appraisal and only $38.1 \%$ was left to other factors. Simple linear regression was done to ascertain the contribution of performance appraisal on teaching output. Scores on performance appraisal $(M=45.89, S D=11.16)$ were regressed with scores on teaching output $(M=35.14, S D=$ $6.01)$ as indicated in the Table 5.

Table 5: Simple Regression Results of Performance Appraisal Versus Teaching Output

\begin{tabular}{lllllll}
\hline $\mathbf{R}$ & $\mathbf{R}^{\mathbf{2}}$ & Ad R $^{\mathbf{2}}$ & $\mathbf{B}$ & Beta & F Stat & Sig. \\
\hline $\begin{array}{l}0.452 \\
* \text { Values significant at }\end{array}$ & .205 level (2-tailed) & & 23.978 & .452 & 69.61 & $.000^{*}$ \\
\hline
\end{tabular}

Findings as per Table 5 showed that the contribution of performance appraisal to teaching output was $R^{2}$ $=0.204$. Hence, performance appraisal made a $20.4 \%$ increase in teaching output. In other words, teaching output was dependent on performance appraisal by $20.4 \%$. The beta and F-statistics (69.61, $p<0.05)$ being positive implied that performance appraisal positively predicted teaching output. Though, the Vice-Chancellors and directors of human resource were responsible for actualizing performance appraisal they, however, complained about the nature and effectiveness of performance appraisal in public universities. This was likely due to the fact that it was the departmental heads and deans of faculties who actually do the appraisal.

One of the Vice-chancellors said that,

.... Much as academic staff is appraised annually, it is wanting in terms of how it is done and its effectiveness. Though staff are able to identify areas of weakness and make proposals on areas of improvement to management for further action..., this does not quickly come through. This is reflected in the failure of universities to excel in teaching, research and consultancy services to the community.

The directors of human resources observed that:

The key stakeholders are not well informed about the process. The key stakeholders include; the academic staff, heads of departments, deans of faculties and directors of schools and institutes. Sometimes you wonder when appraisals are done staff get very good ratings, yet students complaint of delayed marking and release of results, absenteeism of lecturers and generally low level of teaching. Performance appraisal needs to be streamlined to incorporate performance targets, monitoring and feedback.
The findings showed that performance appraisal played a critical contribution towards academic staff performance. This finding was in agreement with Akpan (2016), Adaobi and Uju (2017) who observed that performance appraisal is very critical in ensuring quality assurance, promotion and enhancement of job performance other than simply for promotion as is the case in many universities. Menon (2017) further observed that performance appraisal of lecturers should focus on among other things as a facilitator, evaluator, researcher, mentor, adept academic administrator and charismatic role model. However, the findings showed that training needs identification and performance improvement were still lacking in the public universities appraisal system. The current performance appraisal was done for perfunctory reasons and it lacked effectiveness. The key stakeholders such as the academic staff, departmental heads and faculty or school deans including directors of institutes were not well informed about the process; hence areas of weakness were not correctly identified. This affects proposals to be made on areas of improvement to management for further action. This is the reason why the rating did not reflect performance aspects such as effective teaching and students' assessment.

The second research objective had to determine the relationship between performance appraisal and academic staff research output in selected Ugandan public universities. The researcher had hypothesized that performance appraisal has no statistically substantial correlation with academic staff research output. The Pearson Correlation results in Table 6 revealed a weak positive relationship $(r(2)=.379, p<0.01)$ between performance appraisal and academic staff research output. The stated null hypothesis was rejected and restated as statistically there is a weak positive relationship between performance appraisal and 
academic staff research output. Simple linear regression was done to ascertain the influence of performance appraisal on research output. Scores on performance appraisal $(M=45.89, S D=11.16)$ were regressed with scores on research output $(M=$ 25.97, $S D=4.52$ ) as presented in Table 6 .

Table 6: Simple Regression Results of Performance Appraisal Versus Research output

\begin{tabular}{lllllll}
\hline $\mathbf{R}$ & $\mathbf{R}^{\mathbf{2}}$ & Ad R $^{\mathbf{2}}$ & $\mathbf{B}$ & Beta & F Stat & Sig. \\
\hline 0.379 & .143 & .140 & 18.940 & .379 & 45.384 & $.000^{*}$ \\
$*$ *Values significant at & 0.05 level (2-tailed) & & & & \\
\hline
\end{tabular}

Findings in Table 6 showed the contribution of performance appraisal to research output was $\mathrm{R}^{2}=$ 0.143 . Hence performance appraisal made a $14.3 \%$ improvement in research output. The beta and Fstatistics $(F=45.384, p<0.05)$ were positive implying that financial reward positively predicted research output to some extent. The ViceChancellors clarified the importance of appraisal of academic staff research output. On this issue, one of the Vice-Chancellors intimated that appraisals done by academic departments were not honest enough to enhance research output. He said that

We receive appraisal forms from the departments and find ratings of $75 \%$ above in research engagement and yet on the ground you find limited research output. There are serious issues that affect academic staff research output, many of the academic staff are not actively and directly involved in research activities because of lack of interest.

The directors of human resources generally noted that,

The lack of interest may be due to performance appraisal placing limited emphasis on research and publication and the difficulties in accessing research financing. The research culture in many universities is poor as more emphasis tended to be on teaching the large classes of up to 1000 students.

This finding is in line with Akhter, Siddique, Nur and Alam (2013) who in their study concluded that organisations need to adopt $360^{\circ}$ performance appraisal strategy to improve on employee performance in organisations. Turk (2016) in his report suggested that academic staff should be engaged in contractual performance management for 3-5 years. Within this period the university management would measure among other things the number of theses or dissertations mentored and number of publications made. This finding points to the weakness of management in appraising research activities of academic staff. Management was supposed to interpret performance appraisal results with a higher level of understanding so that the results can be used meaningfully. Surprisingly, management in the selected universities kept wondering what was going on. They seemed to lack a clear pathway for improving the academic staff performance in-terms of research output among the academic staff.

\section{CONCLUSION AND RECOMMENDATIONS}

In relation to performance appraisal and academic staff teaching output. The study found that performance appraisal for academic staff should target the key performance issues of teaching outputs among academic staff. Among other things performance appraisal for academic staff should focus on lecturers as a: - facilitator, evaluator, mentor, adept academic administrator and charismatic role model for students. Academic staffs have to be involved in drafting performance measures and evaluating their performance regularly so that they can own the results and decisions. Results from the interview held with the Vice Chancellors and directors of human resources reveal that departmental heads and faculty or school deans need to be trained on how to effectively carry out performance appraisal of academic staff.

The study findings revealed that performance appraisal can increase academic staff research output substantially when properly implemented. Performance appraisal when tagged to contractual terms will compel academic staff to highly engage in research. It further revealed that emphasis be 
placed on tangible research outputs including publications. The findings revealed that many of the academic staff lacked interest in conducting research because they did not see how it was related to their performance. The recommendations were based on the study results as guided by study findings and conclusions.

1) Ugandan public universities need to revise the existing performance appraisal system to make it more relevant to the key work roles of academic staff of teaching and research outputs.

2) The implementation, monitoring and provision of feedback on performance should be open and practical.

3) Effective mechanisms should be put in work environments to ensure tangible and practical performance management outcomes.

4) The university management should introduce performance management strategies including performance contracts.

\section{REFERENCES}

Adaobi, P., \& Uju, F. (2017). Effect of Academic Staff Promotional Appraisal Measures on Academic Performance of Universities in Anambra State. Online Journal of Arts, Management and Social Sciences, (3), 64-73. 4956.

Akhter, M., Siddique, Nur, E. A., \& Alam, A. (2013). Human Resource Management Practices and its Impact on Employee Performance: A Study of the Cement Industry in Bangladesh. Global Disclosure of Economics and Business, 2(2), 125 - 132.

Akpan, E. (2016). Performance appraisal: A quality assurance tool for lecturers' effectiveness in Nigerian universities. International Journal of Emerging Research in Management \& Technology, 5, (5), 25-33.

Amin, E. M. (2005). Social Science Research Conception Methodology and Analysis. Kampala: Makerere University Printery. Kampala: Makerere University Printery.
Armstrong, M. (2014). A handbook of human resource management practice (10th Edition ed.). London: Kogan Page Ltd.

Balakhanova, K., Danko, A., Midova, O., \& Minasyan, T. (2017). Implementing new performance pay-based schemes in higher educational institutions in Plekhanov Russian University. European Journal of Contemporary Education, 6, (4), 748-756.

Blau, P. M. (1964). Justice in Social Exchange. Sociological Inquiry. 34, 193-206.

Curtis, K. R. (2008). Conducting Market Research Using Primary Data. A Publication of the Western Extension Marketing Committee, 08 13.

Farndale, E., Vidovic, M., \& Rockey, E. (2015). Human Resource Management Policies and Practices in the United States. Society for Human Resource Management (SHRM). Pennsylvania: Center for International HR Studies (CIHRS), School of Labor and Employment Relations, The Pennsylvania State University.

Gaiser, T. J., \& Schreiner, A. E. (2009). A Guide to Conducting Online Research. USA: Sage Publications.

Hashim, M., Rafi, S., Kazmi, A., Ullah, M., \& Kee, H. (2017). Impact of Human Resource Management on perceived performance. A study of teaching faculty in Private Universities of Peshawar, Pakistan. City University Research Journal, Special issue AIC Malaysia, 120-129.

Homans, G. C. (1958). Social Behavior as Exchange. American Journal of Sociology, 63: 597-606.

Kaya, N., Ergun, E., \& Kesen, M. (2014). The effects of human resource management practices and organisational culture types on organisational cynicism. An empirical study in Turkey. British Journal of Arts and Social Sciences, 17 (1), 43-61.

Kiriri, P., \& Gathuthi, E. (2009). Managing performance in Kenyan higher education 
institutions: Application of the balanced scorecard. Management Digest, 1, 514-526.

Krejcie, R. V., \& Morgan, W. D. (1970). Determining sample size for research activities. educational and psychological measurement journal, 607-610.

Kvale, S., \& Brinkmann, S. (2009). Interviews: Learning the Craft of Qualitative Research Interviewing ( 2 ed.). USA: Sage Publications Inc.

Kyaligonza, R., Kimoga, J., \& Nabayego, C. (2015). Funding of Academic Staff's Research in Public Universities in Uganda. Challenges and Opportunities. Makerere Journal of Higher Education, 7 (2), 147-162.

Lavrakas, P. J. (2008). Encyclopedia of Survey Research Methods. USA: Sage Publications.

Marescaux, E., De Winne, S., \& Sels, L. (2013). HR practices and HRM outcomes: the role of basic need satisfaction. Personnel Review, 42(1), 4-27.

Mcgregor, G. P. (2007). Report of the Visitation Committee on Public Universities. Kampala: Government of Uganda.

Menon, G. (2017). Critiquing teacher performance management in higher education institutions. Reviving the observation cube in India. International Journal of Engineering Technology Science and Research, 4, (8), 132145.

Ministry of Public Service. (2018). Data on Academic Staff. Kampala: Unpublished.

NCHE. (2014). National Council for Higher Education. Quality Assurance Framework and Licensing Process.

NCHE. (2016/2017). National Council for Higher Education Report on accredited Higher Education Programmes in Uganda. Kampala: National Council for Higher Education.

Ojukuku, R. M. (2013). Effect of Performance appraisal system on motivation and performance of Academics in Nigerian Public Universities.
Australian Journal of Business and Management Research, 3(3), 20 - 28.

Onen, D. (2014). How to write a successful doctoral research proposal: The Makerere Format. A paper presented on 12 th June 2014 at a Doctoral Colloquium at the College of Education and External Studies. Kampala, Uganda: Makerere University.

Palupi, P., Cahjono, P., \& Dananti, K. (2017). Certified Lecturers' Performance Appraisal Indicators in Web-Based Integrated Evaluation Model. Review of Integrative Business and Economics Research, 6 (1), 157-165.

Roberts, E. (2003). Employee performance appraisal system participation: A technique that works. Public Personnel Management, 32, 8998.

Toppo, L., \& Prusty, I. (2012). From performance appraisal to performance management. IOSR Journal of Business and Management, 3(10), 230-243.

Trochim, W. (2006). The Research methods: Knowledge base (2nd ed.). Retrieved from http://www.social research methods

Türk, K. (2016). Performance management of academic staff and its effectiveness to teaching and research-Based on the example of Estonian universities. Trames, 20(1), 17-36.

Turk, K., \& Roolaht, T. (2017). Appraisal and compensation of the academic staff in Estonian public and private universities. A comparative analysis. A Journal of the Humanities \& Social Sciences, 11 (2), 206-222.

Wamala, R., \& Ssembatya, V. A. (2013). Scholarly Productivity in Developing Countries: An Analysis of Levels and Patterns Among Doctoral Holders in Uganda. Contemporary Issues in Education Research (CIER). 6(2), 163-172.

Whittemore, R., Chase, S. K., \& Mandle, C. L. (2001). Validity in Qualitative Research. 